\title{
Henry Hardware's Moment and the Puritan Attack on Drama
}

Thanks to the colourful and dramatic nature of his actions as mayor of Chester, revealed especially in the pages of Lawrence Clopper's REED volume on that city, Henry Hardware has become a familiar exemplar of Puritan-inspired attacks on drama and other festive activities. 'It was Hardware, after all, who

caused the Gyanntes, in the Mydsomer show to be put downe ${ }^{\circ}\left[\&\right.$ broken $^{\circ}{ }^{\circ}$ and not to goe, The devill in his fethers ... he put Awaye. and the Cuppes and Cannes. And dragon and Naked boyes.... he caused the bull Ringe to be taken vpp And the Leave Lookers were restrayned, for sendinge wine Accordinge to the Aunciente vse and Custome of this Cittye ${ }^{2}$

But Hardware's curtailment of these festivities has thus far been the whole extent of his fifteen minutes of fame in historical scholarship. After that both he himself and his iconoclasm disappear from our view, as if he had spoken his lines and exited stage left forever. This is something of a shame because much more lies here than meets the eye. The timing and circumstances of Hardware's well-known actions help us understand more fully this oft-cited example of Puritan moralism, and thus of Puritan iconoclasm itself, both in provincial towns like Chester and the nation as a whole.

So just who was this man with the amusingly appropriate name, the mayor who banned the traditional representations of the giant and the naked boys, the dragon and the devil in feathers? For that matter, who was he not? And just when did he so disrupt the traditional Midsummer festivities? And, of course, why did he take such a drastic and, at least with many of his fellow Cestrians, unpopular step?

The conventional modern account takes for granted that Hardware served as mayor of Chester three times, in 1559-60, 1575-6, and again in 1599$1600,{ }^{3}$ though this would have made a very old man of him when he came to take off his scarlet robe for the last time. Truth to tell, the many mayors' 
lists with which Chester is so bountifully blessed (save for one or two lists which are a year off in their reckoning!) do all have 'Henry Hardware' as mayor in those years. "That assumption has also encouraged speculation about which of Hardware's terms saw the destructive actions for which we remember him. Clopper's inclination has been to place them in 1575 or 1600; Patrick Collinson rather loosely considers Hardware to have been active 'by the early seventeenth century'.

The question of dating his actions proves the easiest to resolve, at least in somewhat less speculative a manner than exists at present. One of the several descriptions of Hardware disrupting the Midsummer festivities also notes that it was Hardware who 'firste tooke ye toole [toll] from the sergents'. ${ }^{6}$ The two references come virtually in the same breath or - as loose a grammatical concept as this remained in contemporary usage - virtually in the same sentence. We must thus assume that the two reforms came in the same year. And one source at least dates the taking of the tolls from the serjeants to the mayoral term of 1599-1600.' So it seems most likely that his destruction of the giant and his other actions came at the same time. Finally, a reference in another of Chester's antiquarian histories to the putting down of the giant at Midsummer places that event itself in the 1599-1600 mayoral year (in which Midsummer would obviously have come in June 1600) to clinch the point. $^{8}$

This is not the only part of the conventional story of Hardware to falter before close scrutiny. One's suspicions must be raised as well by the fact that the standard heraldic visitation for the county of Cheshire, carried out in 1613, shows Mayor Hardware to have served in 1559-60 and 1575-6 but says nothing of 1599-1600. ${ }^{9}$ Can the herald have missed this last term, especially for a year so close in time to his own visitation? And secondly, the only will for 'Henry Hardware' listed in the most obvious source for wills of prominent people - the files of the Prerogative Court of Canterbury - was proven in the same year as the herald's visitation of 1613. Aside from the fact that (if one had presumably to have been at least thirty-five years of age to be elected mayor of such a large place as Chester) a mayor of 1559 would have been at least seventy-five in 1599 and at least eighty-nine in 1613, the will of 1613 shows a very different set of relatives than the herald shows as belonging to the mayor of 1559-60 and 1575-6. But when we locate the author of that 1613 will on the family tree reconstructed by the herald's visitation, the confusion is immediately resolved. The relations named in the will show the testator to be, not the early Elizabethan mayor at all, but his grandson. In addition, the reconstructed genealogy shows a third Henry Hardware in between. We 
have then, Henry Hardware I, the early Elizabethan mayor, his son Henry Hardware II, and his son in turn, Henry III, the testator of 1613.

But this revelation merely begs another mystery. Which of these three Henry Hardwares served as mayor of 1599 and undertook the iconoclastic actions of that year? Probably not Henry Hardware III who, as it turns out, only first married in 1607 and left a three-year old child at his death in $1613 .{ }^{10} \mathrm{He}$ would clearly have been too young in $1599-1600$ to take the mayoralty in a city with such a relatively large population $\left(c 4,000\right.$ in $\left.1600^{11}\right)$ and as lengthy a wait for high office as Chester. In addition - and one savours the irony - amongst the bequests in his will he notes two musical instruments, a viol and a bandora, and a pair of red silk stockings: not the sort of possessions we would expect from the man who broke up the giant in the Midsummer Show! $!^{12}$ These suspicions are confirmed by the classic historian of Chester, George Ormerod, who notes that this Henry was only baptized in January of $1587 .{ }^{13}$

And the mayor of 1599 was just as clearly not Henry I, as has been assumed. Several indications point to his probable death some years before that time. For one, we know that when a list was made in the year 1590 of those paying a special tax in the city, Mrs Anne Hardware, and not her husband the former mayor, was listed as the householder. ${ }^{14} \mathrm{Had}$ he still been alive in 1590 the list would have had his name rather than hers. Even before this, Henry I may have retired from city life to the village of Little Mouldsworth, seven miles northeast of Chester. We find him listed there, as 'Henry Hardware, gent.', in a visitation of $1580 .{ }^{15}$ And finally, as Ormerod confirms, he turns out to have been married by 1560 and to have died in the Cheshire parish of Tarvin in 1584. ${ }^{16}$ In listing him as mayor in only 1559-60 and 1575-6, the herald of 1613 was not at all making a careless omission: he had done his job with complete accuracy! Henry I was probably born in the 1520 s and died in 1584. Especially in the absence of any surviving will, we have no particular indication of any Puritan sentiment on his part.

By process of elimination, then, the mayor who disrupted the Midsummer Show in 1599-1600 was the second Henry Hardware, serving in his only mayoral year. Our herald tells us that he died three years after leaving office, in the nearby village of Peele, in 1603. But here we have some further reason for doubt, for his will proves to have been dated and witnessed on 7 December 1607 , and to have been proven on 28 February $1607 / 8,{ }^{17}$ with the date of death lying somewhere in between. He describes himself in this document as living at Little Mouldsworth but, sure enough, this locale contained the estate of Peele to which he retired. ${ }^{18}$ 
Now that we have unravelled the identity of the 'right' Henry Hardware, at least a few details of his life fall into place. He proves to have been born in 1561, the only son amongst the six surviving children of his father, Henry I, and his mother, Anne Gee. Anne, too, came from a prominent local family, her father Henry Gee (d. 1579) having served a successful and eventful mayoralty in both 1533 and 1539. Sometime around 1580 Henry Hardware II, 'our Henry', married Elizabeth Aldcrofte of Mouldsworth - the probable origin of the family's presence in the parish of Little Mouldsworth and another link to the ruling elite of Chester city - and most of their five children seem to have been born in the 1580 s.

In January 1583, the same year as his father's death and his daughter Anne's birth, our Henry became a freeman of Chester, as a merchant. ${ }^{19}$ Eight years later, in 1591, he had his first crack at civic office when he was elected a member of the common council of the city, also known as the Forty. ${ }^{20}$ But much to our surprise, Henry forfeited that honour by refusing to take his oath of office. When the assembly voted to fine him the princely sum of $£ 20$ he proved even more obstinate, refusing either to take the oath or to pay the fine. ${ }^{21}$ The assembly, that ruling body made up of the aldermen and the Forty, took great offence at such a brazen act by a young freeman of just thirty years. Its members nullified his election and barred him from their midst. ${ }^{22}$

But if Henry proved to be a stubborn man - firm, self-confident, and true to his own principles - he must also have become an important one. Despite his obstinacy, the assembly gave him a second chance at high office by electing Hardware four years later, and not - ironically - to the lesser and larger council of the Forty, but as one of the eight aldermen of the city. ${ }^{23}$ Without knowing more about the political realities of late Elizabethan Chester, we can only conclude for the moment that Hardware had become too important a figure, or that his personal qualities had somehow become too valuable, to keep him out. The fact that he was selected as mayor just three years later, at the still somewhat tender age of thirty-eight, bears out this impression, and we will return to this interesting question of his rapid political ascendancy in due time.

Beyond his service in those offices, it is hard to know much about Hardware's personal life or even his business. His will offers a few clues, though disappointingly few, and it is impossible to know whether all the details it reveals would have applied to him at the time of his mayoralty or would have accrued in the seven or eight years thereafter, in his retirement to Peele Hall. Still, we do know him for a wealthy man, leaving Peele Hall and its lands in Little Mouldsworth, two water-mills, and a windmill just to his wife Elizabeth. 
To his first son and namesake he left lands in Cheshire, including his other messuage at Bromborough and his stone house in Chester, plus lands in Flintshire as well. He left 800 marks to be divided between two of his daughters, with a third daughter to be provided for by arrangement with her father presumably the balance of a dowry. Save for a library of books, his personal possessions proved unexceptional: they consisted largely of furnishings, two gilt bowls, and a damask suit of clothes. ${ }^{24}$

One has the impression here of a somewhat colourless but hard-working man perched at his death on the threshold of the minor county gentry. Indeed, his son and namesake received a grant of arms from the College of Heralds just months after Henry's death. ${ }^{25}$ One further impression bears heavily on his career and his reputation. It derives from his testamentary formula, whereby he left his soul to Almighty God and his body 'to the earth whence it came', with his burial to be carried out 'as befits a Christian member of Christ's Church'. Its spartan simplicity does nothing to belie his reputation as a pious and righteous man to the end. He no doubt was, as the chronicler confirms, 'a godlye ' ${ }^{\circ}$ ouer $^{1}$ zealous man' with 'a verye worshippfull and A plentefull howse'. ${ }^{26}$

These meagre details of Hardware's life provide at least some context for the year of his mayoralty, a year which ran from his election, the Friday after St Denis' Day (9 October) 1599, to the election of his successor a year later. But for a fuller and more revealing picture, we must now look at Chester itself at that time, and thus at the immediate circumstances surrounding Hardware's actions against the Midsummer festivities. It seems useful, too, to see what we can learn about other aspects of Hardware's mayoralty. And most importantly, we need to see what that information might suggest about the kind of moral reform, most likely of a Puritan nature, which Hardware helped bring to Chester in his mayoral year.

Hardware's term came at a perilous time for Chester. It is not too much to claim that the last years of the century were probably the most difficult years of the whole sixteenth century for Chester; nothing would match it until the destruction of the civil war more than a generation later. Since 1594 Chester had served as one of the chief ports of embarkation for troops en route to Ireland, with all the complications arising from that role. The same period coincided with three of the worst harvests of the century, 1594, 1595, and 1596, which sent food prices rocketing to unprecedented levels. Then, too, the central government placed extraordinary demands on the government and people of the city in the effort to send troops and supplies to Ireland. Finally, the city's merchant community, to which Hardware certainly belonged, had its 
own problems. Though it may have made some money out of supplying troops during the wars, it had also had its own commerce severely disrupted by those hostilities. When many Chester merchants had their goods confiscated by pirates off St Malo sometime in 1598 or 1599 , they tried to imprison some French merchants as pawns for the return of their goods. But when the privy council ordered them to release their hostages, they were compelled to seek alternative forms of compensation. In response to their petition, a panel of three councillors (Sir Thomas Egerton, the earl of Nottingham, and Sir John Fortescue) accepted the validity of their hardship, found them greatly impoverished, and urged the queen to extend a licence to import calfskins as an appropriate compensation for their losses. ${ }^{27}$ At least some of these events need to be examined more closely to allow us to see what Hardware stepped into on his election in October 1599.

As recorded by Chester chroniclers, the build-up of troops en route to Ireland through Chester began in 1594 and reached substantial proportions by the following year. Two thousand seven hundred men passed through the city in the mayoral year of $1595-6,1500$ in 1596-7, 4,200 (or, by one account, $9,900 !^{28}$ ) in $1597-8$, and 6,300 in $1598-9$. In Hardware's year the pace continued. Eight hundred troops came through in mid-February, 3,000 more on the first of March, another 2,130 in mid-July, and a final 800 in September, making 6,730 troops in all. With them, of course, came their supplies and ordnance, carts and horses, and the ships and sailors it took to transport them. And more often than not it took several weeks for these large contingents to pass through. They had to wait until their supplies caught up with them and for favourable winds to sail. That meant, for example, that the 2,600 troops who assembled by the end of February 1599 waited three weeks before sailing in late March; ${ }^{29}$ the 800 foot soldiers who sailed in late September had actually arrived in Chester itself on 21 August, cooling their heels, consuming food and taking up lodging, chasing local women, and brawling with the inhabitants and amongst themselves, before departing five weeks later $!^{30}$

As one might imagine, even with privy council support, the task of billeting these troops stretched the resources of the Cestrians almost beyond endurance. Chester's own population has been estimated at no more than 4,000 or so in these years, ${ }^{31}$ which means that Cestrians were sometimes feeding and housing something on the order of two-and-a-half times the usual number of people for the duration of the war. Though they succeeded in spreading the burden to the surrounding villages, including Bougham, Christleton, Rowton Newton, and others (Hardware's predecessor on one occasion even succeeded in sending 1,000 off to Liverpool),${ }^{32}$ the city found itself continually stretched. 
And as if the numbers alone didn't make things bad enough, the price of wheat rose steadily from 1594 through 1597 . When in the early months of 1596 it hit $28 \mathrm{~s}$ a bushel, one chronicler called it 'more deare than in the memorie of man', but by late April of the same year it soared to $41 \mathrm{~s}$ a bushel. ${ }^{33}$ Conditions did not improve and 1597 saw one of the gravest dearths of the century widespread throughout the entire realm. ${ }^{34}$ Only in $1598 \mathrm{did}$ grain prices subside substantially, drifting down to $11 \mathrm{~s}$ a bushel for wheat by the summer of 1599 . With a more or less average harvest that year it must have been at near normal levels at Hardware's accession in early October. ${ }^{35}$ Yet the experience of such high prices can hardly have made Cestrians any more tolerant of the strangers in their midst, and there can have been little novelty in having them about in the sixth year of their presence. Soldiers being what they were in those years - and many of those sent off to Ireland were conscripts and vagrants impressed into service - the civil order came under constant pressure. Even before the Irish wars broke out Cestrians, like citizens of some other towns, had been obliged to keep certain arms at their homes. ${ }^{36}$ But after the arrival of soldiers in 1594 the public order deteriorated rapidly. The first mayor to contend with this new turn of events, in 1594, ordered a gibbet erected near the high cross as a warning to brawling soldiers. ${ }^{37}$ This was repeared by Mayor Thomas Fletcher in 1597-8 when the soldiers 'weare verye quarrelsome'. ${ }^{38}$

In addition, along with the burdens of feeding, housing, and generally suffering this unwanted presence, Cestrians came in these years more than ever under the watchful eye of the central government. Always hard-pressed to assert their independence from the multiple authorities ringed around them - the bishop and diocese, the County Palatine of Chester and its officials, and the central government as represented primarily by queen, court and council Chester struggled to run its own affairs as much as its charters allowed. This meant the difficult task of fighting off the efforts of the earl of Derby, as chamberlain of the County Palatine, and of Sir Francis Walsingham to secure an important local office for his man, Peter Proby. ${ }^{39}$ It meant constantly trying to put the interests of Chester's citizens, and especially its merchant community, into the consciousness of the privy council and others running the war effort in Ireland.

And it meant, too, living up to its obligations to entertain, at considerable expense, the great figures of state who came through the city in connection with the war effort. In the mayoralty of Hardware's immediate predecessor, Richard Raborne, the earls of Essex, Rutland, Southampton, and Kildaire came through Chester, along with some thirty knights, and various captains 
and other worthies. The mayor and aldermen met them at the city gates on their arrival, banqueted them at the civic hall known as the Pentice, and bestowed gifts upon them as well. Essex received a gold cup worth $£ 10$; others received less valuable gifts according to their status. ${ }^{40}$ Although the funds for these gifts were raised by subscription among the members of the city assembly (comprising the council of Forty, the aldermen, sheriffs, recorder, town clerk, and mayor) rather than the normal revenues of the city, they did add up and the members of the ruling élite found themselves shelling out with some frequency for such occasions.

A similar sort of public occasion brought by the Irish war to Chester was less happy altogether: the funerals and burial of dignitaries killed in the war, whose bodies were returned to England by way of the city. Thus, for example, the funeral of Sir Thomas Egerton, son of the lord keeper of the great seal, knight of the shire for Cheshire and long friend to the city, was held with appropriate pomp and circumstance on 27 September 1599, hardly a fortnight before Hardware's election as mayor. ${ }^{41}$

This then forms the scene which greeted Hardware at his election in early October 1599. As an alderman and member of the assembly for the previous four years he must surely have known what he was getting into. And those members of the city's élite who selected him knew what they were getting in him, a point to which we will shortly return. From what we can reconstruct about Hardware's term in office he brought a no-nonsense approach to all the city's problems, even at the considerable risk of alienating numbers of his fellow townsmen.

From his first recorded meeting of the city assembly as mayor, held on 29 October 1599, he set out to assert greater control over various aspects of city government. He induced the assembly to approve the addition of two auditors to the two who were already in place, thus allowing him to place his own men in that sensitive post. In his next session, on 9 November, he ordered each of the eight aldermen to survey their wards at least once a month. He succeeded in getring assembly approval for a ban on butchers and hucksters opening their shops on the sabbath - an early sign of his Puritan inclinations - and he induced it to approve honorary freeman's status for Richard Vaughan, bishop of Chester. ${ }^{42}$

In his third meeting, held in mid-December, he took further steps to reform local government and bring order to the city. He had the assembly crack down on corrupt practices by the city serjeants and 'leave lookers' (market inspectors), who were known to be accepting bribes for looking the other way when certain transgressions were being committed. He had it disband 
journeymen's brotherhoods that threatened to undermine the interests of the guild masters, and he induced it to award the valuable office of the Pentice clerkship to a local man, Ellis Williams, against the efforts of several privy councillors to prefer their own candidate for the post. ${ }^{43}$ And in the last session before Christmas, as we have noted above, he took the controversial step of taking over from the city serjeants the lucrative collection of the toll on corn sold in the market-place, which he intended to use for his own official expenses and for paying to maintain the market. ${ }^{44}$

As if waiting for him to settle into his post and establish his authority by such means as these, the month of January 1600 brought with it a string of events to which he had to react. ${ }^{45}$ In the middle of the month the River Dee froze over for the first time in several winters and remained frozen for five or six days on end. The event was rare enough to have provoked much merriment among the townspeople, and especially those too young to have seen it before. Many citizens walked and frolicked on the frozen river. Among them was a group of youths who got up a game of football on the ice and, 'not remembering to keep the holy sabbath day, so yt among divers yt hardly escaped, three young men fell through the Ise and were drowned'. ${ }^{46}$ Still others are said to have fallen through but 'fell in and gate out and escaped out of daunger'. ${ }^{47}$ This tragedy, taking place on the sabbath day, 27 January 1600, no doubt caused great grief throughout the community. Many will have taken it as an object lesson in the need to observe the fourth commandment, and Hardware undoubtedly seized the opportunity to make just that point. It may well have had the same effect, if to a lesser extent, as the 'fire from heaven' which would level parts of Dorchester a few years later. ${ }^{48}$

Shortly after these tragic events, on Thursday, 14 February, Lord Mountjoy, lord deputy for Ireland, came to the city with several other dignitaries and military commanders, along with 800 foot soldiers bound for Ireland. On the following Sunday Hardware entertained Mountjoy and other officers at a lavish banquet. Two days after that, on 19 February, he saw the lord deputy pass on by sea to Ireland with many of his troops. ${ }^{49}$

But if townsmen sighed with relief at their departure, they would not do so for long. The first of March brought 2,800 more foot soldiers and 200 horse. They stayed on until the end of April, some eight weeks later. It was not a pleasant time for the Cestrians. As several of the chroniclers noted, the year was very notable for an especially foreboding happenstance: for the first time since 1516, and the last time again for several decades, Black Monday coincided with the New Year day of 25 March. ${ }^{50}$ These portents could well have applied to the city's role as unwilling host. Soldiers fought constantly 
among themselves and menaced the citizenry. One may well imagine friction and even violence between soldiers and townspeople, and townspeople both fighting back and appealing to their mayor for protection and redress. At roughly the same time that Hardware entertained Mountjoy at a banquet, the quarrelling of the soldiers 'caused the cittizens often tymes to Rise'. ${ }^{51}$ Hardware responded by reverting to the tactics of his predecessors in having 'a Gallose set up at the heighe crosse's2 as a warning to those who would break the peace. Some soldiers were arrested by the local constables or citizens and 'some of them had theire eares nayled to peeces of tymber at the high crosse'..$^{53}$

Throughout this period Hardware acted almost as a factotum of the privy council in the government's war effort in Ireland. His letters, which are now preserved in the Salisbury manuscripts and elsewhere, were sent rapidly to Westminster by the elaborate post system in place since the early 1590 s, and show him constantly informing the councillors of news from Ireland, arranging for the provision of transport ships, commenting on the state of troops billeted in his city, organizing the provision of certain military supplies or clothing for those unprepared for battle, and even coordinating the effort to prevent desertion before embarkation. ${ }^{54}$

As Hardware undoubtedly knew, the citizens also needed to be watched closely if the peace were to be kept in these circumstances. In addition to frequent urgings that the aldermen carry out monthly surveys of their wards, and the crackdown on official corruption by the serjeants and 'leave lookers', Hardware's administration seemed determined to stamp out the efforts of some Cestrians to profit illicitly from the hordes of soldiers in their midst. Those who ran bawdy houses, or played games on the sabbath, or ran gaming houses found themselves closely watched, and Hardware's government cracked down hard on those who sold ale without licence. No fewer than 124 local people were fined for breaking the assize of ale in the July sessions alone, with another fifteen fined for breaking the assize of beer. ${ }^{55}$ This astonishing record of convictions at the July sessions covered the period including Midsummer.

That Hardware took these steps out of necessity is obvious. What is less so is that he did so in the face of considerable risk to himself - mostly from the press and menace of the 'visitors' in their midst, the 'Citty so full of gentlemen $\&$ strangers ... all about', ${ }^{56}$ but also partly perhaps from irate citizens. Some no doubt objected to his breach of ancient custom by banning the traditional festivities and also by such crack-downs on what many saw as transgressions against the civil order:

he ruled well yeat he gate greate yll will. Amonge the Commons, for Appooseinge 
hym selfe Againste some Companyes ... orders and agaynste oulde Customes of this Cittye. ${ }^{57}$

Others no doubt feared he was doing too little, blamed him for their constant inconvenience, and urged him on ever more strenuously to the task of bringing order out of chaos. Several of the chroniclers refer to him approvingly as a 'godly ${ }^{\circ}$ ouer ${ }^{\circ}$ zealous man'. ${ }^{58}$ In any event, his unpopularity with 'the commons' cannot be denied, and not very long into his mayoral year he 'comanded 4 freemen out of euery ward daly to wayte on him wth halberds by reason of multitud of souldiers', and perhaps out of fear of the townsmen as well. ${ }^{59}$ Finally, and contrary to one's initial impression, he did not so much abolish the Midsummer festivities altogether as change the symbolism of its events. He not only 'put down' the giant and the naked boys, the devil in feathers, and the dragon, but he 'caused a man in complet Armor to goe before the show in their steed'. ${ }^{6}$ Recognition of Midsummer was not therefore abandoned but rather the folkdoric figures which had traditionally featured in its celebration gave way to a semiotic vocabulary more appropriate to the times. The man in armour was as stark a symbol of the city's resolve to maintain public order as could be devised, unambiguous in its intent to civilians and soldiers alike.

These, then, are the circumstances of Hardware's notorious actions. They suggest, among other things, why a city assembly offended by Hardware's refusal to take his oath of office in 1591, and willing to expel him at that time, came to forgive and re-admit him four years later, and to elevare him to its highest post four years after that. In 1591 all had seemed right in the world of Chester but by 1595 a crisis of public order lay close at hand, and by 1599 the city found itself, if anything, in even deeper distress.

In those circumstances the city's ruling élite needed a much stronger hand than it might otherwise have been willing to tolerate. And if Hardware 'gate greate yll will Amongst the Commons', which we may hardly doubt, his forceful actions seem to have found favour, at least for a time, with those who brought him in. And what is most important of all, those circumstances suggest why traditional processional forms (devil in feathers, naked boys, giant, and all) had been permissible to the local authorities even into the 1590 s, but ceased to be so in 1599 .

This accords well with other observations which have emerged from the current generation of research on the context for the co-option or suppression of traditional festivity. We now know that these events came neither as suddenly nor as universally as once assumed, and that many traditional forms 
of drama endured right into the last years of the century and, in the remotest corners, even beyond. Patrick Collinson and others have used this research to propose that in many parts of the realm the real crackdown, and the cultural wars which ensued thereafter, dated from about the middle of Elizabeth's reign. ${ }^{01}$

That period did indeed see the accentuation of all sorts of tensions in the Elizabethan state. High political concerns became dominated by the Babington Plot (1586) and execution of Mary Staurt (1587), with the Spanish Armada (1589) and the war with Spain, and more than ever with hostilities in France, the Low Countries, and Ireland. They were fed by increased fears of Catholic subversion, and for the health of the queen, and for the determination of the royal succession at her death. They were carried out amidst the deaths of several of Elizabeth's longest-serving and most trusted councillors, ${ }^{62}$ and their replacement by those, like the impetuous earl of Essex, of a new and less restrained temper. ${ }^{63}$ And in the country generally these tensions were severely exacerbated by increased incidence of plague, poverty, and unrest. The climactic point for these difficulties came in the mid-1590s, when severe harvest failures, consequent price rises and poverty, and the Irish War in particular made this the most difficult patch of the reign and (with the late 1550s) one of the two most difficult in the century. ${ }^{6.6}$

For the queen and parliament the times demanded such sweeping responses as the great poor laws of 1597 and 1601. And for those local officials faced with responding to similar pressures, and thus caught between the heavy demands of governance on the one hand and the good will of their fellow townsmen on the other, the times were no less desperate. They made Puritan moral reform more welcome than ever to local ruling élites throughout the realm. Such circumstances did not necessarily resolve contention about traditional festivities, for even in Chester some festivities were sustained or resumed right through to the 1640 s. Nor did they necessarily strive for utrer cessation as opposed to co-option of traditional festivities for more politically appropriate ends.

The suppression or co-option of festive activity by the Puritan forces of the era could easily be seen as a mere act of principle, religious or moral, and indeed there is much to support such an approach. But such suppressive inclinations in general and, indeeed, perhaps the anti-theatrical force of Puritanism in particular, must also be seen as a product of circumstance and an expression of pragmatic necessity. By 1599 events in the city of Chester offer a vivid case in point: Hardware's moment had come. 
Notes

1 Lawrence M. Clopper (ed), Chester, ReEd (Toronto, 1979). See also Patrick Collinson, The Birthpangs of Protestant England (Basingstoke, 1988), 54-5, who uses Hardware to exemplify the Puritan reform of manners in English provincial towns.

2 British Library: Harleian ms 2125, f 45v, as published in Clopper, Chester, 198 (hereafter BL: Harl.).

3 See Clopper, Chester, liv, 526.

4 As Clopper relates, Chester has been unusually blessed with the work of local antiquarians, including Robert and his son David Rogers, Mayor William Aldersey, George Bellin, and especially the four Randle Holmes, all related. In addition to several important breviaries, Clopper identifies no fewer than twenty-seven surviving annotated Mayors' Lists, distribured today mostly in Chester Archives (CA), Cheshire Record Office (CRO), and the British Library (BL). A number will be cited below by their manuscript reference numbers in subsequent notes.

5 Clopper, Chester, 1x, 526; Collinson, Birthpangs, 101.

6 CRo: MS DLT/B/37, Liber N, f 67, published in Clopper, Chester, 199.

7 Chester Assembly Minutes, CA: MS AB/1, ff 256 and 256v.

8 'The Antiquity of Chester', Cro: Ms DLT/B/37, Liber N, $f 67$.

9 PRO: PROB 11/121-2 (1613) and Sir George Armytage and J. Paul Rylands, eds, Pedigrees Made at the Visitation of Cheshire, 1613, Harleian Society, vol 59 (1909), 48, 62, 91, 118-19. Such visitations were carried out periodically by the College of Heralds to verify claims to gentility and the right to a coat of arms. The heralds for these visitations were Richard St George, Norroy King of Arms, and Henry St George, Gent., Bluemantle Pursuivant, though it is not clear which of them did the Hardware family. Heralds employed a variety of means to reconstruct the genealogy of important families as accurately as possible so that claims to gentle status could be assessed.

10 Armytage and Rylands, Visitation of Cheshire, 118-19 and BL: Add. Ms 39,925, f 164.

11 A.R. Myers, 'Tudor Chester', Journal of the Chester Archeological Society 63 (1980), 48.

12 PRO: PROB 11/121/34.

13 George Ormerod, The History of the County Palatine and City of Chester, rev ed, vol 2, pt 1 (London, 1882), 333.

14 BL: Add. ms 11,335, f $21 \mathrm{v}$. 
15 J. Paul Rylands (ed), The Visitation of Chester, 1580, Harleian Society, vol 18 (1882), 11.

16 Ormerod, History of Chester, vol 2, pt 1, 333. This first Henry Hardware was made a freeman of Chester in December 1546, as a draper; J.H.E. Bennett (ed), The Rolls of the Freemen of the City of Chester, 1392-1805, Record Society of Lancashire and Cheshire, vols 51 (1906) and 55 (1908), vol 1, 25. He was probably born in the early 1520 s and therefore would have died in his early sixties.

17 CRO: MS WS 1607, will of Henry Hardware.

18 Ormerod confirms this too, adding that this Henry Hardware, whom we have designated Henry Hardware II, was the first of his line to reside at Peele Hall. Ormerod, History of Cheshire, vol 2, pt 1, 333.

19 Bennett, Chester Freemens' Rolls, vol 1, 57.

20 Chester Assembly Minutes, f 233.

21 Chester Assembly Minutes, ff 234v and 235v; Chester Assembly Files, CA: MS AF/4/26. Twenty-one members voted in favour of the $£ 20$ fine, only six for the lesser fine of $£ 10$.

22 Chester Assembly Minutes, $f 236 \mathrm{v}$.

23 Chester Assembly Minutes, f 245, 6 May, 38 Elizabeth.

24 cRo: WS 1607, will of Henry Hardware.

25 Ormerod, History of Cheshire, vol 2, pt 1, 332.

26 BL: Harl. ms 2125, f 45v, as printed in Clopper, Chester, 198.

27 'Report of Egerton, Nottingham and Fortescue, 1599' [obviously a report to the queen, but dated only with the year, 1599], Historical Manuscripts Commission, Report on the Manuscripts of the Marquess of Salisbury, pt ix (1902), 424-5 [hereafter HMc, Salisbury Papers].

28 CRO: MS DLT/B/37, Liber N, f 65v.

29 нмс, Salisbury Papers, 106-7, 113.

30 BL: Add. Ms 29,780, ff 136-42.

31 Myers, 'Tudor Chester', 48.

32 нмс, Salisbury Papers, 96-7.

33 CRO: $\mathrm{Ms}$ DLT/B/37, Liber N, f 64v.

34 Andrew B. Appleby, Famine in Tudor and Stuart England (Stanford, 1978), 114 and $133-44$.

35 CRO: Ms DLT/B/37, Liber N, ff 63-6. Appleby, Famine, 136, fig 16; Joan Thirsk (ed), The Agrarian History of England and Wales, vol 4 1500-1640 (Cambridge, 1967), especially Table I, 820.

36 Thus in 1590 freemen were ordered by the mayor to keep a headpiece and halberd at the ready. CRo: $\mathrm{MS}$ DLT/B/37, Liber $N, f 63 \mathrm{v}$. 
37 CRO: MS DLT/B/37, Liber N, f 64 .

38 CRO: MS DLT/B/37, Liber N, f 65v.

39 Chester Assembly Minutes, ff 207 et seq.

40 BL: Harl. Ms 2125, f 45.

41 BL: Harl. Ms 2125, f 45.

42 Chester Assembly Minutes, ff 256 and 256v.

43 Chester Assembly Minutes, ff 256v-7.

44 Chester Assembly Minutes, f 258.

45 By the old style of dating which applied in England at that time, the New Year began on 25 March, but our 'new style' or modern system of dating has been employed here, with 1600 beginning on 1 January instead.

46 BL: Harl. Ms 2057, f 31v.

47 BL: Harl. Ms 2125 , f $45 \mathrm{v}$.

48 David Underdown, Fire from Heaven: Life in a Seventeenth Century Country Town (New Haven and London, 1992).

49 BL: Harl. Ms 2057, f 31v.

50 CRO: MS DLT/B/37, Liber N, f 66-66v.

51 BL: Add. Ms 29,779, f 31.

52 BL: Add. Ms 29,779, f 31; 'Gallose' here means 'gallows'.

53 BL: Harl. MS 2125, f 45.

54 HMC, Salisbury Papers, 12, 136, 137, 186, 189, 233, 268, 323, 337, 339, and 349.

55 Chester Mayor's Books, CA: MS MB/28, ff 65v, 66-6v, and 77v-9v. As a county in and of itself, Chester had quarter sessions, with the mayor and aldermen sitting as JPs. Beer differed from ale in those bygone days because it had the addition of hops as a preservative.

56 BL: Add. Ms 2125, f 45v.

57 BL: Harl. Ms 2125, f 45v. A similar phrasing is employed in other Mayors' Lists which distinguish Chester's recorded past, including BL: Harl. 1944, f $90-90 \mathrm{v}$.

58 See BL: Harl. ms 1944, f 90-90v; Harl. 2125, f 45v.

59 BL: Harl. Ms 2125, f 45v.

60 BL: Harl. ms 2125, f 45v, as printed in Clopper, Chester, 198.

61 Collinson, Birthpangs, 54-6 and 112-15.

62 The earl of Leicester in 1588, Walter Mildmay in 1589, both Francis Walsingham and the earl of Warwick in 1590, and Christopher Hatton in 1591.

63 This theme of contrasting generations of Elizabethan political leaders received its classic exposition in Anthony Esler, The Aspiring Mind of the Elizabethan Younger Generation (Durham, N.C., 1966). 
54 ROBERT TITTLER

64 See, for example, Peter Clark, 'A Crisis Contained? The Condition of English Towns in the 1590's', in Clark (ed), The European Crisis of the 1590s, Essays in Comparative History (1985) 44-62. 